\title{
Involvement of MAP Kinase in Angiotensin II-Induced Phosphorylation and Intracellular Targeting of Neuronal AT Receptors $_{1}$
}

\author{
Hong Yang, ${ }^{2}$ Di Lu, ${ }^{2}$ Gavin P. Vinson, ${ }^{1}$ and Mohan K. Raizada ${ }^{2}$ \\ ${ }^{1}$ Department of Biochemistry, Queen Mary and Westfield College, London E1 4NS, England, and 2Department of \\ Physiology, College of Medicine, University of Florida, Gainesville, Florida 32610
}

MAP kinase stimulation is a key signaling event in the $A T_{1}$ receptor $\left(A T_{1} R\right)$-mediated chronic stimulation of tyrosine hydroxylase and norepinephrine transporter in brain neurons by angiotensin II (Ang II). In this study, we investigated the involvement of MAP kinase in $A T_{1} R$ phosphorylation to further our understanding of these persistent neuromodulatory actions of Ang II. Ang II caused a time-dependent phosphorylation of neuronal $A T_{1} R$. This phosphorylation was associated with internalization and translocation of $A T_{1} R$ into the nucleus. MAP kinase also stimulated phosphorylation of neuronal $A T_{1} R$. The conclusion that MAP kinase participates in neuronal $A T_{1} R$ phosphorylation and its targeting into the nucleus is supported further by the following. (1) MAP kinase-mediated phosphory- lation of $A T_{1} R$ was blocked by the $A T_{1} R$ antagonist losartan; (2) $A T_{1} R$ co-immunoprecipitated with MAP kinase; (3) MAP kinasekinase inhibitor PD98059 attenuated Ang II-induced phosphorylation of $\mathrm{AT}_{1} \mathrm{R}$; and (4) PD98059 blocked Ang II-induced nuclear translocation of $\mathrm{AT}_{1}$ Rs. In summary, these observations demonstrate that Ang II-induced phosphorylation of $A T_{1} R$ is mediated by its activation of MAP kinase. A possible role of $A T_{1} R$ translocation into the nucleus on persistent neuromodulatory actions of Ang II has been discussed.

Key words: angiotensin II; $A T_{1}$ receptor; phosphorylation; nuclear receptor; nuclear localization signal (NLS); MAP kinase; hypothalamic-brainstem neurons
Angiotensin II (Ang II) exerts its neuromodulatory actions on the brain by regulating the activities of neuronal enzymes involved in the turnover of catecholamines (Steckelings et al., 1992; Raizada et al., 1994). It binds to the $\mathrm{AT}_{1}$ receptor $\left(\mathrm{AT}_{1} \mathrm{R}\right)$ subtype and stimulates tyrosine hydroxylase $(\mathrm{TH})$, dopamine $\beta$-hydroxylase $(\mathrm{D} \beta \mathrm{H})$, and norepinephrine transporter (NET) (Lu et al., 1996a; Yu et al., 1996). In fact, whereas acute stimulation by Ang II involves post-transcriptional events, chronic exposure of neurons with Ang II results in a persistent stimulation of these neuromodulatory activities and involves transcription of $\mathrm{TH}, \mathrm{D} \beta \mathrm{H}$, and NET genes (Lu et al., 1996a; Yu et al., 1996). These observations are intriguing and suggest that the neuronal $\mathrm{AT}_{1} \mathrm{R}$, a member of G-protein-coupled receptors (GPCRs), may be unique in that persistent stimulation of neuromodulation by Ang II is independent from its desensitization induced by Ang II. In view of this uniqueness of neuronal $\mathrm{AT}_{1} \mathrm{R}$, we set out to investigate the signal transduction mechanism involved in Ang II regulation of neuromodulation. These studies have revealed a distinct signaling pathway for this GPCR involving Ras-Raf-1 and MAP kinase (Yang et al., 1996a), suggesting that $\mathrm{AT}_{1} \mathrm{R}$ interaction with the heterotrimetric $\mathrm{Gq}$ would result in the dissociation of $\mathrm{G}_{\beta \gamma}$ from $\mathrm{G} \alpha \cdot \mathrm{G}_{\beta \gamma}$, then, directly or through the recruitment of one or more cytoplas-

\footnotetext{
Received Oct. 3, 1996; revised Dec. 9, 1996; accepted Dec. 10, 1996.

This work was supported by National Institutes of Health Grant HL33610. We thank Jennifer Brock for preparation of this manuscript and Elizabeth Brown for preparation of neuronal cultures. Expert technical support from the Center for Structural Biology and the Interdisciplinary Center for Biotechnology Research, University of Florida, is gratefully acknowledged.

Correspondence should be addressed to Dr. Mohan K. Raizada, Professor and Associate Dean for Graduate Education, Department of Physiology, College of Medicine, University of Florida, P.O. Box 100274, Gainesville, FL 32610.

Drs. Hong Yang and Di Lu have contributed equally to this study.

Copyright (C) 1997 Society for Neuroscience $\quad 0270-6474 / 97 / 171660-10 \$ 05.00 / 0$
}

mic or membrane-associated factors, causes the activation of Ras, which leads to the activation of MAP kinase (Van Corven et al., 1993; Burgering and Bos, 1995; Inglese et al., 1995; Shaw, 1995). The role of the pleckstrin homology $(\mathrm{PH})$ domain in this communication between $G_{\beta \gamma}$ and Ras has already been proposed for other GPCRs (Inglese et al., 1995; Shaw, 1995). Thus, it would seem that $G_{\beta \gamma}$ and not $G \alpha$ plays a role in the $A_{1} R$-mediated signaling process involving MAP kinase.

Phosphorylation of GPCRs by GPCR kinases (GRKs) is an important step for termination of the signaling pathway stimulated by the interaction of agonist to its receptor (Lefkowitz, 1993; Permont et al., 1995). Because the $\mathrm{AT}_{1} \mathrm{R}$ signaling mechanism leading to the cellular actions in the neurons seems to be unique, we decided to investigate the phosphorylation of this receptor by Ang II and the potential role of this phosphorylation on its persistent stimulatory actions of Ang II on the neurons. Our observations demonstrate that Ang II stimulates phosphorylation of $\mathrm{AT}_{1} \mathrm{R}$ and that this may be mediated by MAP kinase. Phosphorylation is associated with $\mathrm{AT}_{1} \mathrm{R}$ internalization and its targeting into the nucleus.

\section{MATERIALS AND METHODS}

One-day-old Wistar Kyoto rats were obtained from our breeding colony, which originated from Harlan Sprague Dawley (Indianapolis, IN). DMEM, plasma-derived horse serum (PDHS), and trypsin $(150 \mathrm{U} / \mathrm{mg})$ were from Central Biomedia (Irwin, MD). [ $\left.\gamma^{-32} \mathrm{P}\right] \mathrm{ATP}(3000 \mathrm{Ci} / \mathrm{mmol})$, $\left[{ }^{32} \mathrm{P}\right]$-orthophosphate $(1 \mathrm{mCi}=37 \mathrm{MBq})$, and chemiluminescence assay reagents were from DuPont NEN (Boston, MA). Nitrocellulose membranes were from Micron Separations (Westboro, MA). Ang II and myelin basic protein (MBP) were purchased from Sigma (St. Louis, MO). Losartan potassium (Dup 753) was a gift from DuPont/Merck (Wilmington, DE). PD123319 was from RBI (Natick, MA). PD98059 was from Calbiochem (La Jolla, CA). $\left.{ }^{125} \mathrm{I}\right]-\mathrm{Sar}^{1}-\mathrm{Ile}^{8}$-Ang II (specific activity = $2200 \mathrm{Ci} / \mathrm{mmol}$ ) was purchased from Dr. Robert Speth, Washington State 
University (Pullman, WA). Polyclonal anti-rabbit-AT $\mathrm{R}_{1}$ antibody (306, catalog number SC579) was obtained from Santa Cruz Biotechnology (Santa Cruz, CA). It was prepared by using a peptide corresponding to amino acids $s^{306-359}$ of the $\mathrm{AT}_{1} \mathrm{R}$. The antibody was specific for $\mathrm{AT}_{1} \mathrm{R}$ and was mouse, rat, and human reactive. No cross-reaction of the $A_{1} T_{1} R$ antibody with the $\mathrm{AT}_{2} \mathrm{R}$ was observed. Monoclonal antibody to $\mathrm{AT}_{1} \mathrm{R}$ was prepared by using a synthetic peptide corresponding to amino acids $^{8-17}$ of the $\mathrm{AT}_{1} \mathrm{R}$ and characterized as described elsewhere (Barker et al., 1993). Anti-MAP kinase (C-14), a polyclonal antibody that specifically recognizes ERK-2 and to a much lesser extent ERK-1, and protein A/G PLUS-agarose were purchased from Santa Cruz Biotechnology. An anti-rat MAP kinase polyclonal antibody (ERK I-III) that recognized the p42 MAP kinase and p44 MAP kinase and activated mouse GST-p42 MAP kinase were from Upstate Biotechnology (Lake Placid, NY). All other reagents were purchased from Fisher Scientific (Pittsburgh, PA) and were the highest quality available.

\section{Hypothalamus-brainstem neuronal cells in primary culture}

Hypothalamus-brainstem areas of 1-d-old Wistar Kyoto rat brains were dissected, and brain cells were dissociated by trypsin. The hypothalamic block contained the paraventricular nucleus and the supraoptic, anterior, lateral, posterior, dorsomedial, and ventromedial nuclei. The brainstem block contained medulla oblongata and pons. Dissociated brain cells were plated in poly-L-lysine-precoated tissue culture dishes $\left(2 \times 10^{7}\right.$ cells $/ 100$ $\mathrm{mm}$ diameter dish or $3 \times 10^{6}$ cells $/ 35 \mathrm{~mm}$ diameter dish) in DMEM containing $10 \%$ PDHS, and neuronal culture was established essentially as described previously (Raizada et al., 1984, 1993). The cultures were allowed to grow for 10-15 d before their use in experiments. Immunohistochemical analysis has indicated repeatedly that these cultures contain $85-90 \%$ neuronal cells and $10-15 \%$ astroglial cells (Raizada et al., 1984, 1993).

\section{Immunoprecipitation}

Neuronal cultures, established in 100-mm-diameter culture dishes, were treated with Ang II. The cell lysates were prepared by adding $1 \mathrm{ml}$ lysis buffer [25 mM Tris-HCl, pH 7.4, $150 \mathrm{~mm} \mathrm{NaCl}, 1 \%$ Triton X-100, $1 \%$ deoxycholic acid, $1 \mathrm{~mm}$ sodium orthovanadate, $10 \mathrm{~mm}$ sodium fluoride, 10 mM sodium pyrophosphate, $2.5 \mathrm{~mm}$ EDTA, $1 \mathrm{~mm}$ phenylmethylsulfonyl fluoride (PMSF), $10 \mu \mathrm{g} / \mathrm{ml}$ aprotinin, and $0.8 \mu \mathrm{g} / \mathrm{ml}$ leupeptin] and scraping the cells off the culture dish. Cell lysates were centrifuged at $6000 \times \mathrm{g}$ for $10 \mathrm{~min}$ at $4^{\circ} \mathrm{C}$, and the protein content of resulting supernatants was determined using a Bio-Rad (Richmond, CA) Bradford protein assay kit. Lysates containing $400 \mu \mathrm{g}$ of protein were subjected to an immunoprecipitation protocol as follows. Lysates were incubated with $1 \mu \mathrm{g}$ of rabbit anti-AT $\mathrm{T}_{1} \mathrm{R}$ or anti-MAP kinase antibody overnight at $4^{\circ} \mathrm{C}$. Immunoprecipitates were collected on protein A/G PLUS-agarose, washed three times with lysis buffer, and used in additional experiments (Yang et al., 1996a).

\section{Immunoblotting}

Immunoprecipitates were suspended in $20 \mu \mathrm{l}$ of Laemmli's sample buffer in a boiling water bath for $3 \mathrm{~min}$ and then centrifuged. The resulting supernatants $(10 \mu \mathrm{l})$ were electrophoresed in $10 \%$ SDS-PAGE, and proteins were transferred onto nitrocellulose membrane. The membrane was blocked by $5 \%$ nonfat dry milk in TBST $(20 \mathrm{~mm}$ Tris $\mathrm{HCl}, \mathrm{pH} 8.0,150$ $\mathrm{mm} \mathrm{NaCl}$, and $0.05 \%$ Tween 20) for $1 \mathrm{hr}$ followed by incubation for $1 \mathrm{hr}$ at room temperature with rabbit anti-MAP kinase antibody or rabbit anti- $\mathrm{AT}_{1} \mathrm{R}$ antibody. Protein-bound antibody was detected by incubation of the membrane with horseradish peroxidase-labeled secondary antibody and enhanced by chemiluminescence assay reagents. The bands recognized by the primary antibody were visualized by exposure to film (Yang et al., 1996a).
A

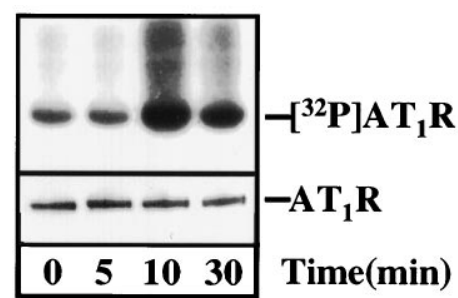

B
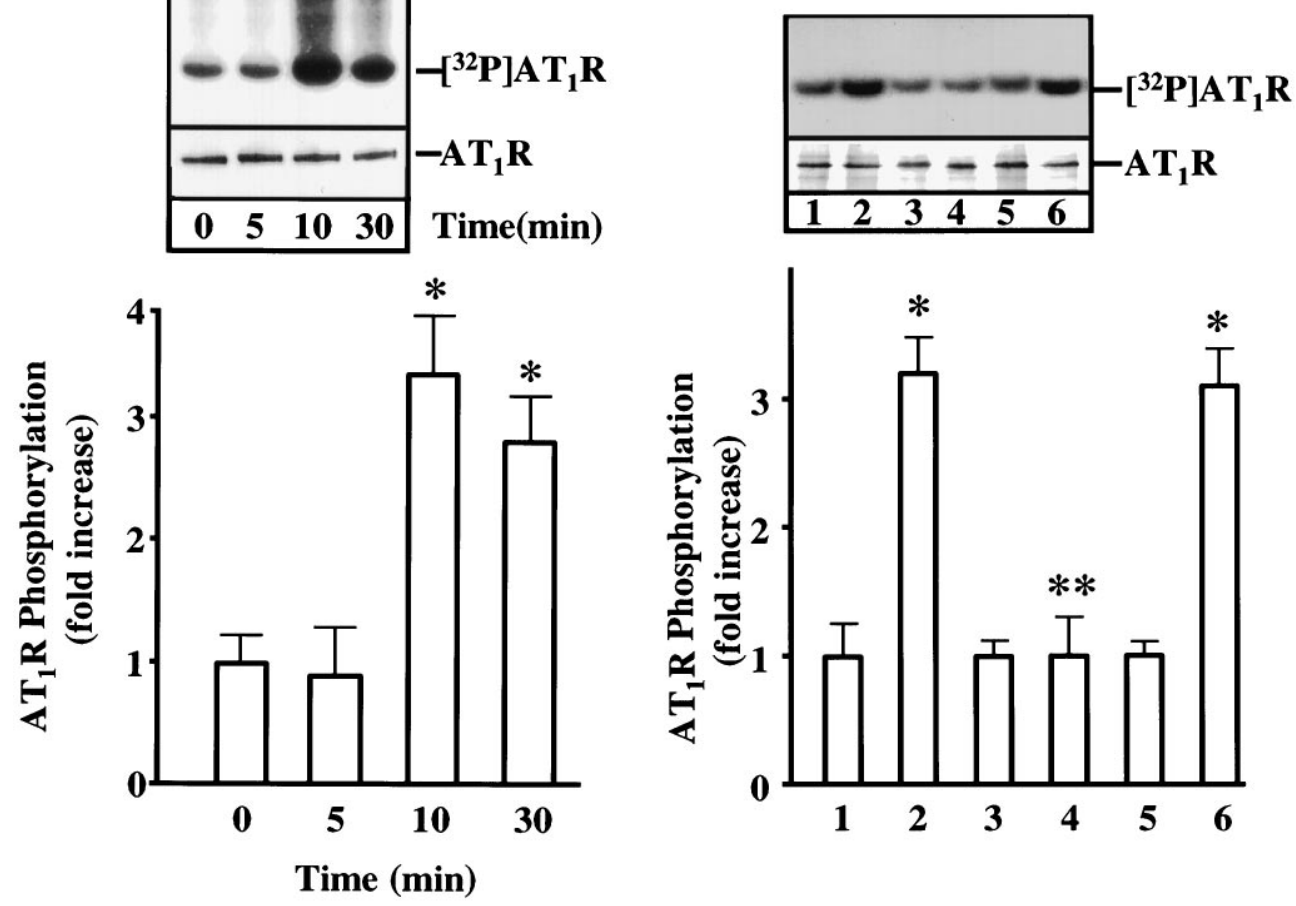

Figure 1. Ang II stimulation of $\mathrm{AT}_{1} \mathrm{R}$ phosphorylation. $A$, Time course. Neuronal cultures were prelabeled with $\left[{ }^{32} \mathrm{P}\right]-$ orthophosphate for $4 \mathrm{hr}$, and cells were lysed in lysis buffer as described in Materials and Methods and incubated with 100 nM Ang II for the indicated time periods. Incorporation of TCA-precipitable $\left.{ }^{32} \mathrm{P}\right]$ was measured, and $\sim 4.3 \times 10^{6} \mathrm{dpm}$ were used to immunoprecipitate $\mathrm{AT}_{1}$ Rs. $\left[{ }^{125} \mathrm{I}\right]-$ $\mathrm{Sar}^{1}$-Ile ${ }^{8}$-Ang II (30 fmol $/ \mathrm{mg}$ ) binding activities were subjected to SDS-PAGE and autoradiography, as described in Materials and Methods. The same membrane was probed with $\mathrm{AT}_{1} \mathrm{R}$ antibody $\left(A T_{1} R\right)$ after the development of the autoradiogram to normalize for $\left[{ }^{32} \mathrm{P}\right]$ incorporated into $\mathrm{AT}_{1} \mathrm{R}$ donated as $\left[{ }^{32} \mathrm{P}\right]-\mathrm{AT}_{1} \mathrm{R}$. Top, Representative autoradiogram; bottom, quantitation of radioactive band representing $\mathrm{AT}_{1} \mathrm{R}$ from three separate experiments. Data from three separate experiments were averaged $( \pm \mathrm{SE})$ and presented as fold increase by using zero time control as baseline. Single asterisk shows significant $(p<0.05)$ difference from 0 time control. $B$, Receptor specificity. Cultures were incubated without $(1,3,5)$ or with $(2,4,6)$ $100 \mathrm{~nm}$ Ang II for $10 \mathrm{~min}$ in the absence (1, 2 ) or presence $(3,4)$ of $10 \mu \mathrm{M}$ losartan or $10 \mu \mathrm{M}$ PD123319 $(5,6)$. Data were analyzed essentially as described for $A$. Top, Representative autoradiogram; bottom, quantitation of $\left[{ }^{32} \mathrm{P}\right]-\mathrm{AT}_{1} \mathrm{R}$ after normalization of densities with immunoreactive $\mathrm{AT}_{1} \mathrm{R}$. Data are presented as fold increase by using control as baseline. Single asterisks show significant difference $(p<0.05)$ from 1 , whereas double asterisk shows significant difference $(p<0.05)$ from 2 . 


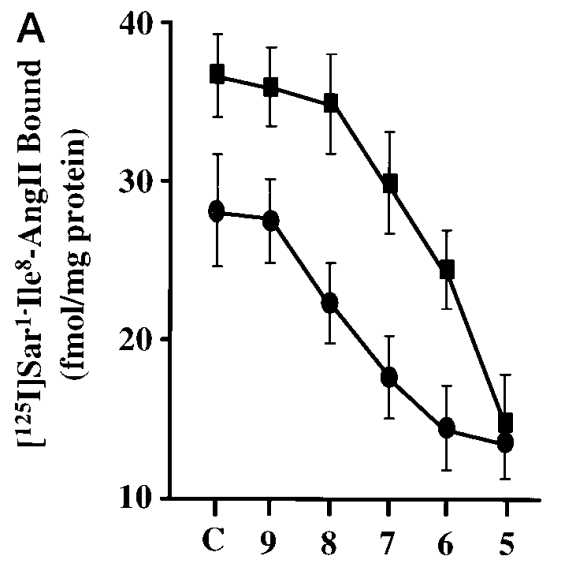

Losartan $(-\log M)$
B

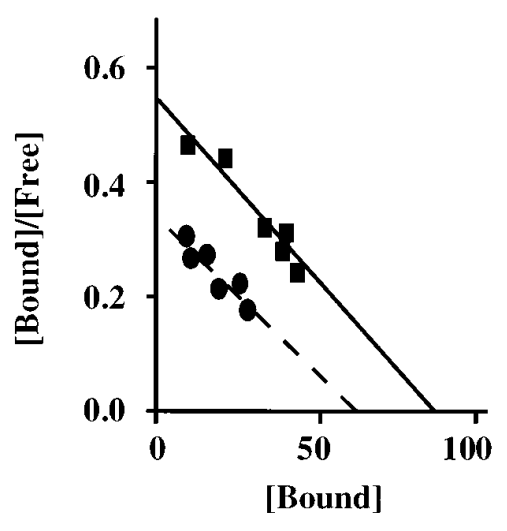

Figure 2. Effect of Ang II on [ $\left.{ }^{125} \mathrm{I}\right]-\mathrm{Sar}^{1}-\mathrm{Ile}^{8}$-Ang II binding to cell surface $\mathrm{AT}_{1} \mathrm{Rs}$ in neurons. Neuronal cultures were incubated with $100 \mathrm{~nm}$ Ang II for $15 \mathrm{~min}$ at $37^{\circ} \mathrm{C}$. This was followed by measurement of cell surface binding of $\left[{ }^{125} \mathrm{I}\right]-\mathrm{Sar}^{1}$-Ile ${ }^{8}$-Ang II to $\mathrm{AT}_{1} \mathrm{Rs}$, essentially as described in Materials and Methods. $A$, Competition-inhibition of un-

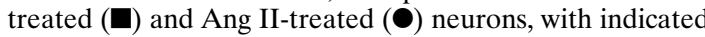
concentrations of losartan. $B$, Scatchard analysis of the data from Figure $3 A$.

\section{$\left[{ }^{125} I\right]-$ Sar $^{1}-$ Ile $e^{8}$-Ang II binding assay}

Binding in $A T_{1} R$ immunoprecipitates. Cell-free lysates were subjected to immunoprecipitation by rabbit-anti- $\mathrm{AT}_{1} \mathrm{R}$ antibody as described above. Immunoprecipitates containing $\mathrm{AT}_{1} \mathrm{R}$ were collected on protein $\mathrm{A} / \mathrm{G}$ PLUS-agarose and washed three times with lysis buffer and once with binding buffer [PBS, $\mathrm{pH} 7.2$, containing $1.0 \%$ bovine serum albumin (BSA)]. Binding of $\left[{ }^{125} \mathrm{I}\right]-\mathrm{Sar}^{1}-\mathrm{Ile}^{8}$-Ang II to these immune complexes was carried out as described previously (Abramowski and Staufenbiel, 1995). In brief, immune complexes containing $\sim 30$ fmol of $\left[{ }^{125} \mathrm{I}\right]-\mathrm{Sar}^{1}$ Ile $^{8}$-Ang II binding activity suspended in $0.5 \mathrm{ml}$ binding buffer were incubated with $1 \mathrm{nM}\left[{ }^{125} \mathrm{I}\right]-\mathrm{Sar}^{1}-\mathrm{Ile}^{8}$-Ang II in the presence of $10 \mu \mathrm{M}$ PD123319 for $1 \mathrm{hr}$ at room temperature to determine total binding. $\mathrm{PD} 123319$, an $\mathrm{AT}_{2} \mathrm{R}$ antagonist, was used in all binding assays to block the binding of $\left[{ }^{125} \mathrm{I}\right]-\mathrm{Sar}^{1}-\mathrm{Ile}^{8}$-Ang II to $\mathrm{AT}_{2} \mathrm{Rs}$. In addition, increasing concentrations of losartan $(1 \mathrm{nM}-10 \mu \mathrm{M})$ were used for the competitioninhibition experiments. All reactions were run in triplicate. The binding reaction was terminated by filtration and collection of $\left[{ }^{125} \mathrm{I}\right]-\mathrm{Sar}^{1}-\mathrm{Il}^{8}-\mathrm{Ang}$ II bound to receptors on Whatman GF/B filters presoaked with $0.3 \%$ polyethyleneimine. Filters were washed three times with ice-cold PBS, $\mathrm{pH}$ 7.2 , to remove unbound radioligand, and bound radioactivity was counted by a Beckman DP5500 gamma counter. Binding was expressed as femtomoles of $\left[{ }^{125} \mathrm{I}\right]-\mathrm{Sar}^{1}$-Ile ${ }^{8}$-Ang II bound per milligrams of cellular protein used to immunoprecipitate the receptor. Specific binding was calculated by subtracting the $\left[{ }^{125} \mathrm{I}\right]-\mathrm{Sar}^{1}-\mathrm{Ile}^{8}$-Ang II bound to complex in the presence of losartan from that bound in its absence. Scatchard analysis was carried out from the competition-inhibition experiments for the calculation of $K_{\mathrm{d}}$ and $B_{\max }$ using the EBDA-ligand Program (Elsevier-Biosoft).

Binding in intact neurons. Cell surface $\mathrm{AT}_{1} \mathrm{R}$ levels were measured with the use of intact neuronal cells attached to culture dishes. Neuronal cultures were established in 35-mm-diameter culture dishes, and binding of $\left[{ }^{125} \mathrm{I}\right]-\mathrm{Sar}^{1}-\mathrm{Ile}^{8}$-Ang II to $\mathrm{AT}_{1} \mathrm{R}$ was determined as follows. After treatment with Ang II, growth medium was aspirated from culture dishes, and cultures were rinsed with $\mathrm{PBS}, \mathrm{pH} 7.2$, with 2-5 min incubation between rinses. This allowed for the dissociation of any unlabeled Ang II that bound to cell surface $\mathrm{AT}_{1} \mathrm{Rs}$ during preincubation. Triplicate cultures were incubated with $1 \mathrm{ml}$ of reaction mixture containing $1.0 \mathrm{nM}$ $\left[{ }^{125} \mathrm{I}\right]-\mathrm{Sar}^{1}-\mathrm{Ile}^{8}$-Ang II, $1.0 \%$ BSA, and $10 \mu \mathrm{M}$ PD123319 for the determination of total binding. In addition, triplicate cultures that also contained increasing concentrations of losartan $(1 \mathrm{nM}-10 \mu \mathrm{M})$ were used for the competition-inhibition experiments. Binding was performed at $4^{\circ} \mathrm{C}$ for $60 \mathrm{~min}$; the dishes were then washed three times with ice-cold PBS, $\mathrm{pH}$ 7.4. Cells were dissolved in $0.1 \mathrm{~N} \mathrm{NaOH}(0.5 \mathrm{ml} / \mathrm{dish})$, and data for the quantitation of cell surface $\mathrm{AT}_{1} \mathrm{R}$ were analyzed essentially as described previously (Yang et al., 1996b).

\section{Fractionation of neurons into nuclear fraction}

Neuronal cultures, established in 100-mm-diameter tissue culture dishes, were rinsed twice with PBS, $\mathrm{pH} 7.4$, and cells were collected by scraping the monolayer with the help of a Teflon scraper. Cells were fractionated into total cell lysate, nuclear, and cell extract without nuclear fraction, essentially as described elsewhere with minor modifications (Abmayr and Workman, 1992). Briefly, the cell pellet was incubated in a solution containing $10 \mathrm{mM} \mathrm{KCl}, 1.5 \mathrm{~mm} \mathrm{MgCl}, 10 \mathrm{~mm}$ HEPES, pH 7.0, $0.5 \mathrm{~mm}$ dithiothreitol (DTT), and $0.2 \mathrm{~mm}$ PMSF for $10 \mathrm{~min}$ at $4^{\circ} \mathrm{C}$ followed by homogenization with 15 gentle strokes using a type $B$ pestle in a Dounce homogenizer. A $>90 \%$ lysis of neurons was accomplished by this method, as evidenced by a microscopic examination. Certain amounts of homogenates were saved and used for whole-cell lysate fraction. The remaining homogenates were centrifuged at $3300 \times g$ for $15 \mathrm{~min}$, and nuclear fraction was collected. This nuclear fraction was used directly for confocal microscopy to localize $\mathrm{AT}_{1} \mathrm{R}$ immunoreactivity. For other biochemical determinations, the nuclear pellet was lysed by nuclear lysis buffer $(20 \mathrm{~mm}$ HEPES, pH 7.9, 25\% glycerol, $1.5 \mathrm{~mm} \mathrm{MgCl}_{2}, 0.2 \mathrm{~mm}$ EDTA, $0.2 \mathrm{~mm}$ PMSF, $0.5 \mathrm{~mm}$ DTT, and $30 \mathrm{~mm} \mathrm{KCl}$ ). The nuclear extract was collected by centrifugation at $25,000 \times g$ for $30 \mathrm{~min}$ at $4^{\circ} \mathrm{C}$. Both nuclear and cell extract without nuclear fraction were dialyzed overnight against a dialysis buffer $(20 \%$ glycerol, $20 \mathrm{~mm}$ HEPES, pH 7.9, $100 \mathrm{~mm} \mathrm{KCl}, 0.2 \mathrm{~mm}$ EDTA, 0.2 mM PMSF, and 0.5 mM EDTA). Nuclear specific protein, lamin B, and cytosolic enzyme aldolase were used to determine the relative purity of these fractions (Clegg, 1984; Gerace, 1986). Nuclear fractions contained $100 \%$ of immunoreactive lamin B, whereas $4-8 \%$ of the total aldolase was found associated with this fraction. Aldolase activity was found predominately $(96 \%)$ in the fraction of cell extract without nuclei, which contained no detectable lamin B. Distribution of these proteins in these compartments is consistent with the presence of traditional markers and shows that this fractionation yielded relatively pure nuclear preparation from neurons. Equal amounts of proteins in both fractions were used to immunoprecipitate $\mathrm{AT}_{1} \mathrm{Rs}$ as described above.

\section{Measurement of MAP kinase activity by in-gel assay}

MAP kinase activity was measured essentially as described elsewhere (Yang et al., 1996a). Briefly, neuronal cells grown in 100-mm-diameter

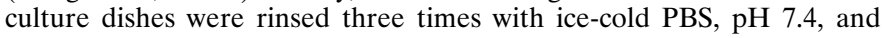
lysed by incubation with $0.5 \mathrm{ml}$ of lysis buffer $(25 \mathrm{~mm}$ Tris- $\mathrm{HCl}, 25 \mathrm{~mm}$ $\mathrm{NaCl}, 1 \%$ Triton $\mathrm{X}-100,1 \%$ deoxycholic acid, $0.1 \%$ SDS, 1 mm sodium orthovanadate, $10 \mathrm{~mm}$ sodium fluoride, $10 \mathrm{~mm}$ sodium pyrophosphate, 0.5 mM EGTA, $1 \mathrm{~mm}$ PMSF, $10 \mu \mathrm{g} / \mathrm{ml}$ aprotinin, and $0.8 \mu \mathrm{g} / \mathrm{ml}$ leupeptin) for $10 \mathrm{~min}$ at $4^{\circ} \mathrm{C}$. Cell-free lysates containing equal amounts of protein from triplicate culture dishes were pooled and incubated with $1 \mu \mathrm{g}$ of rabbit anti-AT $\mathrm{T}_{1} \mathrm{R}$ antibody at $4^{\circ} \mathrm{C}$ overnight. Immunoprecipitates were collected on protein $\mathrm{A} / \mathrm{G}$ PLUS-agarose, centrifugated, and electrophoresed on $10 \%$ SDS-PAGE containing $0.5 \mathrm{mg} / \mathrm{ml} \mathrm{MBP}$. The gel was then washed twice in $20 \%$ 2-propanol, $50 \mathrm{~mm}$ Tris- $\mathrm{HCl}, \mathrm{pH} 8.0$, and twice in $50 \mathrm{~mm}$ Tris-HCl, pH 8.0, containing 5 mm 2-mercaptoethanol. Each wash lasted for $1 \mathrm{hr}$ at room temperature with gentle shaking. MAP kinase activity was measured by incubating the gel with $40 \mathrm{~mm}$ HEPES, $\mathrm{pH} 8.0,2 \mathrm{mM}$ DTT, $10 \mathrm{mM} \mathrm{MgCl}_{2}, 0.5 \mathrm{mM}$ EGTA, $40 \mu \mathrm{M}$ ATP, and $10 \mu \mathrm{Ci}\left[\gamma^{-32} \mathrm{P}\right] \mathrm{ATP}$ $(3000 \mathrm{Ci} / \mathrm{mm})$ for $30 \mathrm{~min}$ at room temperature, followed by autoradiography as described previously (Yang et al., 1996a).

\section{Phosphorylation of $A T_{1} R$ by exogenous MAP kinase}

Phosphorylation of $\mathrm{AT}_{1} \mathrm{Rs}$ after their immunoprecipitation from neuronal cell lysate by anti-rabbit- $\mathrm{AT}_{1} \mathrm{R}$ antibody was carried out with the use of exogenous MAP kinase by a protocol based on that described by Paxton et al. (1994). Briefly, neuronal cell lysates were prepared as 

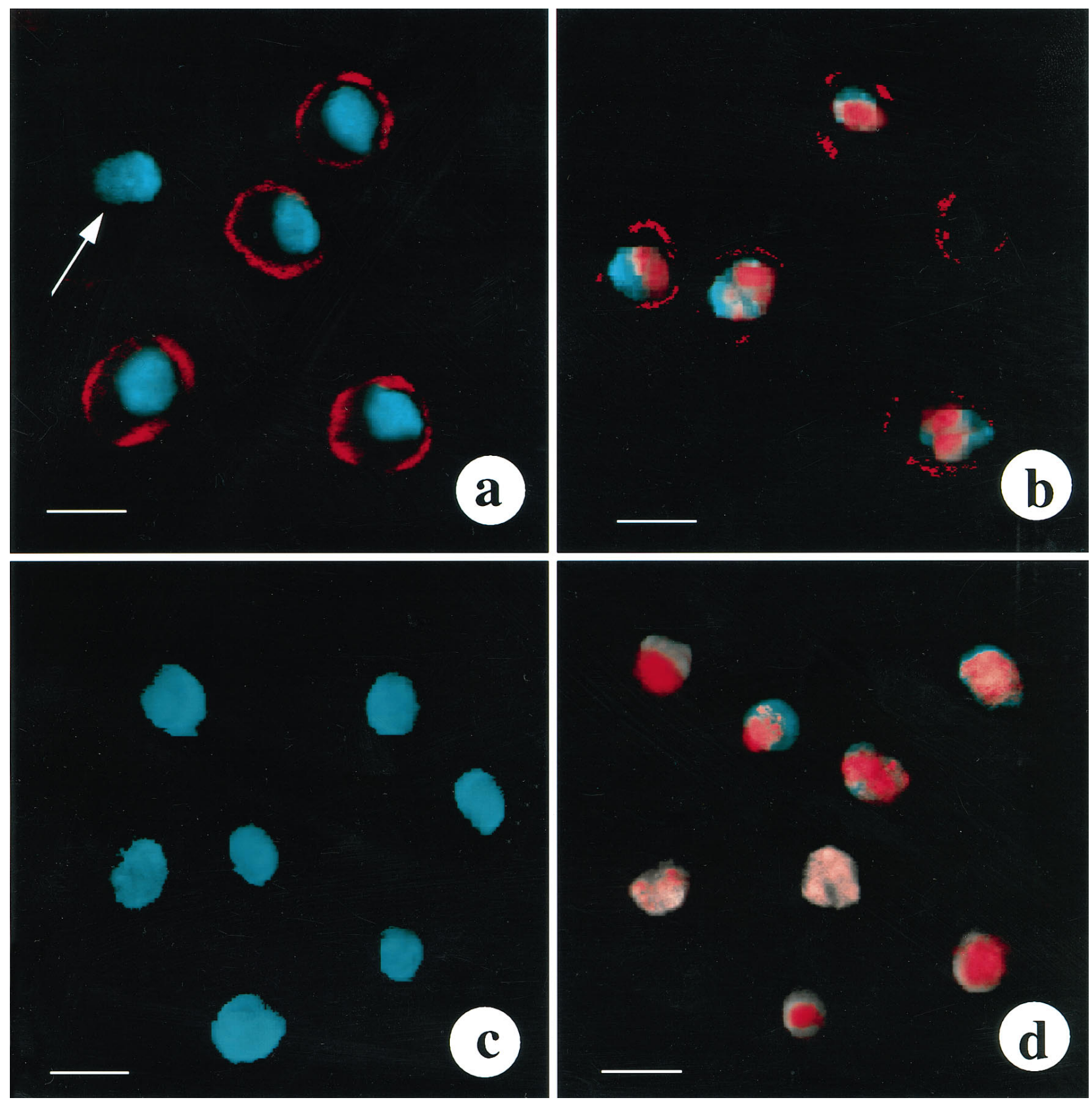

Figure 3. Effect of Ang II on localization of $\mathrm{AT}_{1} \mathrm{Rs}$ in neurons after Ang II treatment. Neuronal cultures were incubated without $(a, c)$ or with $(b, d)$ $100 \mathrm{~nm}$ Ang II for $30 \mathrm{~min}$ at $37^{\circ} \mathrm{C}$. Samples $a$ and $b$ were used to conduct confocal microscopy after immunofluorescent staining, essentially as described in Materials and Methods. Samples $c$ and $d$ were subjected to a nuclear isolation protocol, essentially as described elsewhere (Abmayr and Workman, 1992). This was followed by plating the nuclei on the slide, fixation, permeabilization, immunofluorescence with the use of monoclonal anti-AT $\mathrm{R}_{1}$ antibody, and confocal microscopy as described in Materials and Methods. Arrow represents an $\mathrm{AT}_{1} \mathrm{R}$ negative neuron. Scale bars, $4 \mu \mathrm{m}$.

described above. Lysates containing $400 \mu \mathrm{g}$ protein were incubated with $1 \mu \mathrm{g}$ rabbit anti- $\mathrm{AT}_{1} \mathrm{R}$ antibody overnight at $4^{\circ} \mathrm{C}$, and $\mathrm{AT}_{1} \mathrm{R}$ immunoprecipitates were collected on protein $\mathrm{A} / \mathrm{G}$ PLUS-agarose and rinsed three times with lysis buffer and once with kinase assay buffer $(50 \mathrm{~mm}$ HEPES, pH 7.5, 0.1 mm EDTA, 0.015\% Triton X-100). Immunoprecipitates were suspended in $10 \mu \mathrm{l}$ kinase assay buffer. For measurement of phosphorylation, $10 \mu \mathrm{l}$ of $\mathrm{AT}_{1} \mathrm{R}$ immunoprecipitate $\left(\sim 30 \mathrm{fmol}\left[{ }^{125} \mathrm{I}\right]\right.$ Sar $^{1}$-Ile ${ }^{8}$-Ang II binding activity) was incubated without or with $0.3 \mathrm{U}$ of MAP kinase, $0.1 \mathrm{mg} / \mathrm{ml} \mathrm{BSA}$, and $0.2 \% \quad \beta$-mercaptoethanol in a final volume of $20 \mu \mathrm{l}$. The reaction was started by the addition of $10 \mu \mathrm{l}$ of ATP mixture $\left(0.3 \mathrm{~mm}\right.$ ATP, $30 \mathrm{~mm} \mathrm{MgCl}$, and $200 \mu \mathrm{Ci}\left[\gamma_{-}{ }^{32} \mathrm{P}\right]$-ATP in $1 \mathrm{ml}$ kinase assay buffer) and run for $0-30 \mathrm{~min}$ at $30^{\circ} \mathrm{C}$. After the reaction was stopped by the addition of phosphoric acid, samples were blotted onto Whatman GF/B filter paper, and then the paper was washed four times with ice-cold $0.5 \%$ phosphoric acid and finally once with acetone, essentially as described elsewhere (Paxton et al., 1994). The paper was allowed to dry, and radioactivity was quantitated by liquid scintillation counting. Reaction mixtures that contained $3 \mu \mathrm{g}$ of MBP instead of $\mathrm{AT}_{1} \mathrm{R}$ immunoprecipitate were used as the standard for phosphorylation assays. In certain experiments, the kinase reaction was stopped by the addition of $5 \times$ Laemmli's sample buffer instead of phosphoric acid; samples were heated and centrifuged, and the supernatant was electrophoresed in $10 \%$ SDS-PAGE. Proteins were transferred to polyvinylidene difluoride membrane and subjected to autoradiography. The same membrane was later probed with $\mathrm{AT}_{1} \mathrm{R}$ antibody. [ $\left.{ }^{32} \mathrm{P}\right]$-labeled $\mathrm{AT}_{1} \mathrm{R}$ bands were quantitated using a UVP Imagestore 5000 system and quantitated with the use of the SW5000 Gel Analysis program. Data were normalized for equal loading by analysis of the densities of unlabeled $\mathrm{AT}_{1} \mathrm{R}$ immunoreactivity. 

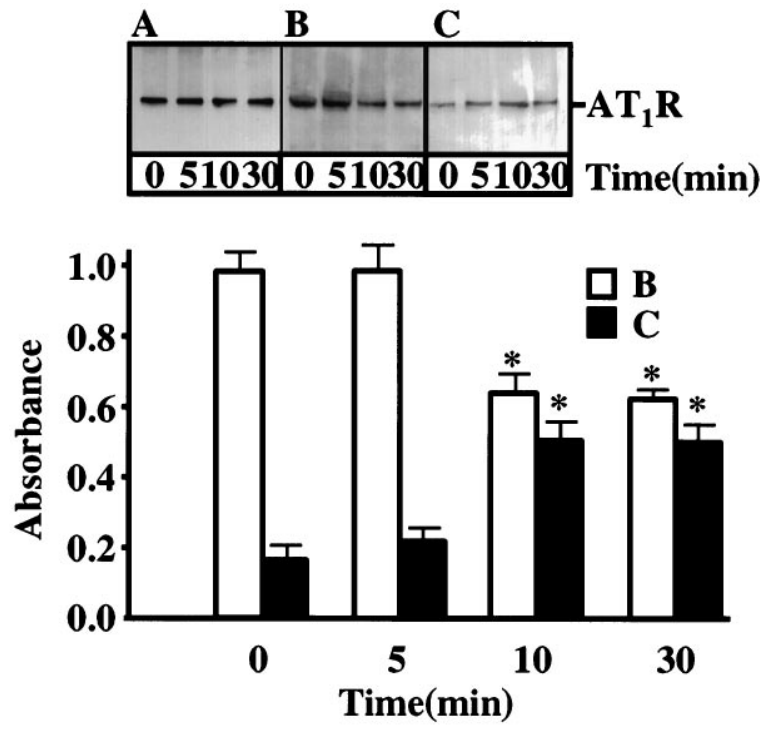

Figure 4. Ang II-induced redistribution of $\mathrm{AT}_{1} \mathrm{Rs}$ in neurons. Neuronal cultures, established in 100-mm-diameter culture dishes, were treated with $100 \mathrm{~nm}$ Ang II for the indicated time periods. Whole cells $(A)$, nuclear fraction $(C)$, and rest of the cell fraction $(B)$ were collected (Abmayr and Workman, 1992). $\mathrm{AT}_{1} \mathrm{Rs}$ from these fractions were immunoprecipitated and quantitated essentially as described in Materials and Methods. Top, A representative immunoblot; bottom, quantitation of bands representing $\mathrm{AT}_{1} \mathrm{R}$ from three separate experiments. Data are presented as absorbance of and have been normalized with zero time absorbance for rest of cell fraction. Asterisk indicates significantly different $(p<0.05)$ from zero time.

\section{Labeling of neuronal cells with $\left[{ }^{32} P\right]$-orthophosphate and analysis of phosphorylated $A T_{1} R$}

Neuronal cultures were established for $15 \mathrm{~d}$ in $100-\mathrm{mm}$-diameter culture dishes. Growth medium was removed, and cultures were incubated with phosphate-free DMEM containing dialyzed PDHS for $4 \mathrm{hr}$ at $37^{\circ} \mathrm{C}$ followed by prelabeling the cells with $1 \mathrm{mCi} / \mathrm{ml}{ }^{32} \mathrm{P}$-orthophosphate for 4 $\mathrm{hr}$ at $37^{\circ} \mathrm{C}$. Ang II was added, and incubation was continued for various time periods. Cultures were immediately rinsed three to four times with ice-cold PBS, and lysates were prepared in lysis buffer as described above. Cell lysates were centrifuged at $6000 \mathrm{~g}$ for $10 \mathrm{~min}$. Proteins from $100 \mu \mathrm{l}$ of each cell lysate were precipitated by $10 \mu \mathrm{l}$ of $100 \%$ trichloroacetic acid (TCA), and incorporation of $\left[{ }^{32} \mathrm{P}\right]$ was measured by liquid scintillation counter. Samples containing the same amounts of $\left[{ }^{32} \mathrm{P}\right]$ radioactivity were used to immunoprecipitate $\mathrm{AT}_{1} \mathrm{Rs}$, essentially as described above. Agarose beads containing $\mathrm{AT}_{1} \mathrm{R}$ were collected at $3000 \mathrm{~g}$ for $10 \mathrm{~min}$, washed three times in lysis buffer, resuspended in $20 \mu \mathrm{l}$ of Laemmli's sample buffer, and heated to $100^{\circ} \mathrm{C}$ for $3 \mathrm{~min}$. Supernatant was electrophoresed in $10 \%$ SDS-PAGE, and proteins were transferred to PVDF membrane (Bio-Rad). The membrane was dried and subjected to autoradiography at $-80^{\circ} \mathrm{C}$ for $2-3 \mathrm{~d}$. After autoradiography to detect $\left[{ }^{32} \mathrm{P}\right]$-labeled $\mathrm{AT}_{1} \mathrm{Rs}$ $\left(\left[{ }^{32} \mathrm{P}\right]-\mathrm{AT}_{1} \mathrm{R}\right)$, the same membrane was probed for total $\mathrm{AT}_{1} \mathrm{Rs}$ by immunoblot analysis. Densities of bands in $\left[{ }^{32} \mathrm{P}\right]-\mathrm{AT}_{1} \mathrm{R}$ and $\mathrm{AT}_{1} \mathrm{R}$ were quantitated with the use of UVP Imagestore System and SW5000 Gel Analysis program. Data were normalized for equal loading with the use of total $\mathrm{AT}_{1} \mathrm{R}$.

\section{Immunofluorescence localization of $A T_{1} R$}

Neuronal cultures established in 35-mm-diameter dishes were rinsed with PBS, $\mathrm{pH} 7.4$, and fixed in $-10^{\circ} \mathrm{C}$ methanol for 5 min. After preincubation with fetal bovine serum for $30 \mathrm{~min}$ at $37^{\circ} \mathrm{C}$ to suppress nonspecific binding of the antibody, cells were incubated with a mouse monoclonal anti- $\mathrm{AT}_{1} \mathrm{R}$ antibody at $1 \mu \mathrm{g} / \mathrm{ml}$ concentration in PBS containing $0.5 \%$ BSA. After the cells were rinsed five times with PBS at room temperature, they were incubated for an additional $60 \mathrm{~min}$ at $37^{\circ} \mathrm{C}$ with rhodamine-conjugated anti-mouse IgG. Cells were counterstained with DAPI to identify nuclear DNA and nuclei as described elsewhere (Lubke et al., 1994). Appropriate controls in which either primary antibody was replaced by growth medium without $\mathrm{AT}_{1} \mathrm{R}$ antibody or without secondary antibody were also run in parallel to determine nonspecific staining. The cells were processed for fluorescent microscopy as described previously (Lu et al., 1996a,b). DAPI-stained nuclei and rhodamine staining representing $\mathrm{AT}_{1} \mathrm{R}$ were examined with the use of a confocal microscope. Data were collected by using a $40 \times$ /numerical Olympus IMT-2 inverted light microscope in which focal position, excitation lamp shutter, excitation and remission barrier filters, and digital camera shutter were under the control of a stand-alone computer (Hiraoka et al., 1991; Swedlow et al., 1993). Twodimensional images were processed as described previously (Lu et al., 1996a,b).

\section{Data Analysis}

Each experiment was conducted in triplicate culture dishes. Cells in these dishes were derived from multiple brains of 1-d-old rats. Each experiment was repeated three times, unless indicated otherwise. Images from autoradiograms were captured in UVP Imagestore 5000 system, and radioactive bands were quantitated essentially as described elsewhere (Yang et al., 1996a,b). Data from at least three autoradiograms were quantitated and corrected for equal loading by quantitating total $\mathrm{AT}_{1} \mathrm{R}$ immunoreactivity or other standard protein. They are presented as mean \pm SE. Statistical analysis was performed by using ANOVA and Dunnett's tests.

\section{RESULTS}

\section{Effects of Ang II on $\mathrm{AT}_{1} \mathrm{R}$ phosphorylation}

$\left[{ }^{32} \mathrm{P}\right]$-orthophosphate-prelabeled neuronal cultures were incubated with $100 \mathrm{~nm}$ Ang II to determine whether occupancy by Ang II of $\mathrm{AT}_{1}$ Rs stimulates its phosphorylation. Figure $1 A$ shows that $\mathrm{AT}_{1} \mathrm{R}$ antibody immunoprecipitated a radiolabeled band of $\sim 49$ $\mathrm{kDa}$. Ang II caused a time-dependent increase in the radioactivity represented by this band, and an approximately sixfold stimulation was observed within $10 \mathrm{~min}$. The molecular weight (MW) of this band corresponded to the reported size for the $\mathrm{AT}_{1} \mathrm{R}$ by this antibody (Paxton et al., 1993). Figure $1 B$ shows that Ang IIinduced phosphorylation of the receptor was mediated by Ang II interaction with the $\mathrm{AT}_{1} \mathrm{R}$, because it was blocked by losartan, an $\mathrm{AT}_{1} \mathrm{R}$ subtype-specific antagonist, and not by PD123319, an $\mathrm{AT}_{2} \mathrm{R}$ subtype antagonist.

The effect of Ang II on $\mathrm{AT}_{1} \mathrm{R}$ internalization was determined next, because studies have shown that phosphorylation of the receptor is key in the agonist-induced internalization of many GPCRs (Lohse, 1993; Freedman et al., 1995). Neuronal cultures were treated with $100 \mathrm{nM}$ Ang II for $15 \mathrm{~min}$, followed by measurement of $\left[{ }^{125} \mathrm{I}\right]-\mathrm{Sar}^{1}-\mathrm{Ile}^{8}$-Ang II binding to cell surface $\mathrm{AT}_{1} \mathrm{R}$. Figure $2 A$ shows that Ang II caused a significant decrease in the binding of $\left[{ }^{125} \mathrm{I}\right]-\mathrm{Sar}^{1}-\mathrm{Ile}^{8}$-Ang II to cell surface $\mathrm{AT}_{1}$ Rs compared with untreated cultures. The decrease was the result of a decrease in $B_{\max }(60 \pm 9 \mathrm{fmol} / \mathrm{mg}$ protein in Ang II-treated vs $86 \pm 10$ $\mathrm{fmol} / \mathrm{mg}$ protein in control neurons) rather than changes in the $K_{\mathrm{d}}$ values $(6.0 \pm 0.7 \mathrm{~nm}$ in Ang II-treated vs $5.2 \pm 0.8 \mathrm{~nm}$ in control neurons) (Fig. 2B). This indicated that phosphorylation by Ang II is associated with internalization of $\mathrm{AT}_{1} \mathrm{Rs}$. Immunofluorescence combined with confocal microscopy was used to determine the fate of $\mathrm{AT}_{1} \mathrm{R}$ after neurons were treated with Ang II. Figure $3 a$ shows that $\mathrm{AT}_{1} \mathrm{Rs}$ were diffusely and uniformly distributed on the plasma membrane of neuronal cell soma. Incubation with $100 \mathrm{nM}$ Ang II for 30 min resulted in an $\mathrm{AT}_{1} \mathrm{R}$ fluorescence accumulation into the nuclear region, as evidenced by their colocalization with DAPI, a nuclear-specific stain (Fig. 3b). Conformation of the nuclear localization of $\mathrm{AT}_{1} \mathrm{R}$ immunoreactivity was further achieved by immunofluorescence staining in isolated nuclei with the use of a monoclonal anti- $\mathrm{AT}_{1} \mathrm{R}$ antibody. Figure $3 d$ shows that nuclei isolated from $100 \mathrm{~nm}$ Ang II-treated neurons have significant $\mathrm{AT}_{1} \mathrm{R}$ staining. Nuclei from untreated neurons lacked this staining (Fig. $3 c$ ). $\mathrm{AT}_{1} \mathrm{R}$ staining on the plasma membrane and in the nucleus was specific, because controls without primary anti- 


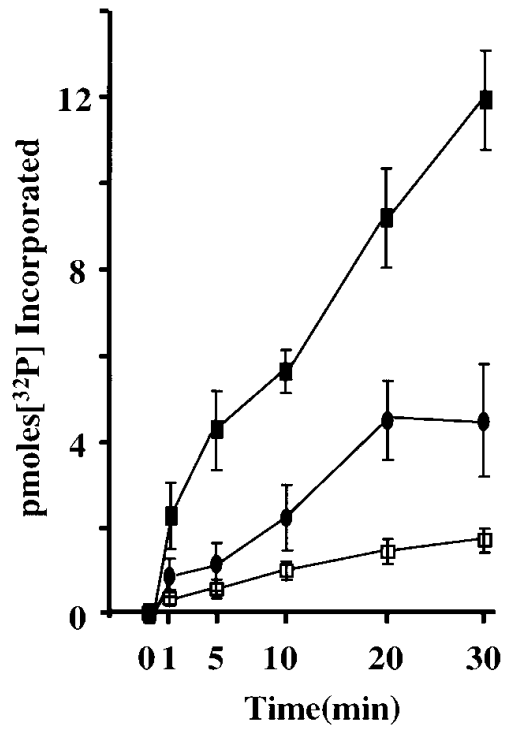

Figure 5. In vitro phosphorylation of $\mathrm{AT}_{1} \mathrm{Rs}$ by MAP kinase. $\mathrm{AT}_{1} \mathrm{R}$ was isolated by immunoprecipitation of neuronal cell lysates with the polyclonal $\mathrm{AT}_{1} \mathrm{R}$ antibody as described in Materials and Methods. Immunoprecipitate containing $\sim 30 \mathrm{fmol} / \mathrm{mg}$ protein $\left[{ }^{125} \mathrm{I}\right]-\mathrm{Sar}^{1}-\mathrm{Ile}^{8}$-Ang II binding activity was incubated without $(\square-\square)$ or with $(\bullet) 0.3 \mathrm{U}$ of MAP kinase at $30^{\circ} \mathrm{C}$ for indicated time periods to determine the incorporation of $\left[{ }^{32} \mathrm{P}\right]$ into $\mathrm{AT}_{1} \mathrm{R}$, essentially as described in Materials and Methods. MBP $(3 \mu \mathrm{g})$ was used as assay control (ם). Data are presented as picomoles of radioactivity incorporated as a function of time and are mean $\pm \mathrm{SE}$ of three experiments.

body or secondary antibody showed no staining. Specificity of nuclear staining of the $\mathrm{AT}_{1} \mathrm{R}$ was further confirmed with the use of the polyclonal anti- $\mathrm{AT}_{1} \mathrm{R}$ antibody. This antibody provided essentially the same result as that seen with the monoclonal antibody, although the latter antibody gave sharper staining with minimum background.

Nuclear fractions of control and Ang II-treated neuronal cultures were isolated, and immunoblotting was carried out to confirm the Ang II-induced nuclear translocation of $\mathrm{AT}_{1} \mathrm{Rs}$ depicted by the confocal microscopic data. Figure $4 A$ shows that the intensity of the immunoreactive band corresponding to $\mathrm{AT}_{1} \mathrm{R}$ of the whole cells did not change after treatment with $100 \mathrm{~nm}$ Ang II. Its intensity, however, was increased in the nuclear fraction of neurons treated with Ang II as a function of time (Fig. 4C). This was associated with a decrease in immunoreactivity in the extract from the rest of the cell (Fig. $4 B$ ). As a consequence, the nuclear fraction showed a threefold increase in $\mathrm{AT}_{1} \mathrm{R}$ immunoreactivity in $30 \mathrm{~min}$.

\section{Role of MAP Kinase in $\mathbf{A T}_{\mathbf{1}} \mathbf{R}$ phosphorylation}

We studied the identity of protein kinase, which may be involved in Ang II-stimulated phosphorylation of $\mathrm{AT}_{1} \mathrm{R}$. The role of MAP kinase was investigated in view of our previous observation that Ang II stimulates this kinase in neuronal cells (Lu et al., 1996b; Yang et al., 1996a) and that MAP kinase may be involved in the translocation of proteins across the nuclear membrane. In addition, the role of this kinase on phosphorylation of estrogen and epidermal growth factor receptors has been reported (Morrison et al., 1993; Kato et al., 1995). $\mathrm{AT}_{1} \mathrm{R}$ was immunoprecipitated with the polyclonal $\mathrm{AT}_{1} \mathrm{R}$ antibody, and immunoprecipitates were incubated with exogenous MAP kinase in the presence of $\left[{ }^{32} \mathrm{P}\right]$ ATP. Figure 5 shows that a time-dependent phosphorylation of
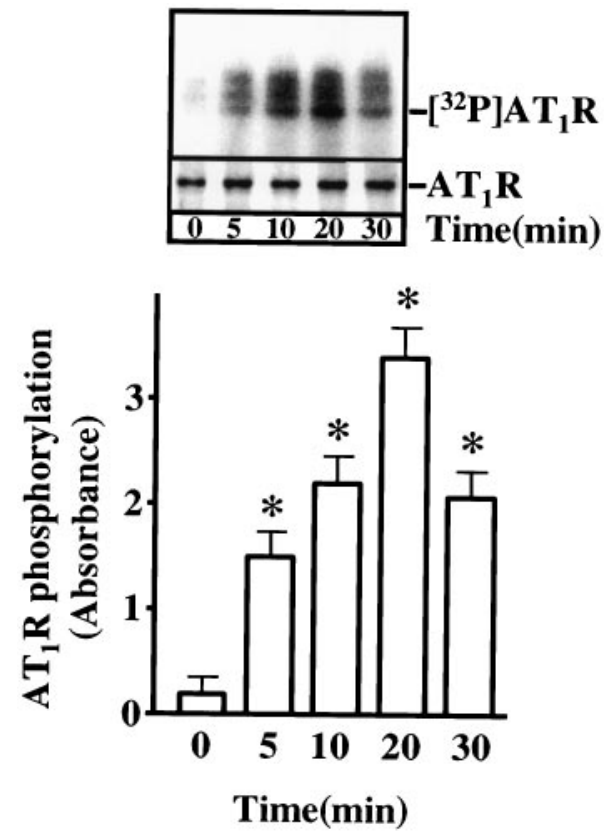

Figure 6. Immunoblot analysis of in vitro phosphorylated $\mathrm{AT}_{1}$ Rs by MAP kinase. $\mathrm{AT}_{1} \mathrm{Rs}$ were subjected to MAP kinase-mediated phosphorylation essentially as described in legend to Figure 5. Phosphorylated receptor preparation was electrophoresed in 10\% SDS-PAGE, and protein was transferred to membrane and subjected to autoradiography. Top, A representative autoradiogram; bottom, quantitation of $\left[{ }^{32} \mathrm{P}\right]$-labeled band corresponding to $\mathrm{AT}_{1} \mathrm{R}$ after normalization with $\mathrm{AT}_{1} \mathrm{R}$ immunoreactivity for equal loading. Data are mean $\pm \mathrm{SE}(n=3)$. Asterisks indicate significantly different $(p<0.05)$ from zero time control.

$\mathrm{AT}_{1} \mathrm{R}$ was seen in the immunoprecipitates, even in the absence of exogenous MAP kinase. Phosphorylation was at low levels and was the first indication that endogenous MAP kinase could be co-immunoprecipitated with $\mathrm{AT}_{1} \mathrm{R}$. Incubation with exogenous MAP kinase significantly increased the incorporation of $\left[{ }^{32} \mathrm{P}\right]$ into the immunoprecipitate in a time-dependent manner. The phosphorylation reached a plateau in 20 min with $0.3 \mathrm{U}$ of MAP kinase, at which time it was fourfold higher than control samples without exogenous MAP kinase. MBP phosphorylation was used as a standard for MAP kinase substrate in these experiments. SDS-PAGE of in vitro phosphorylated $\mathrm{AT}_{1} \mathrm{R}$ immunoprecipitate by MAP kinase showed a $\left[{ }^{32} \mathrm{P}\right]$-labeled band that corresponded to the molecular size of $\mathrm{AT}_{1} \mathrm{R}(\sim 49 \mathrm{kDa})$ (Fig. 6). Density of this band increased as a function of time, which paralleled the in vitro phosphorylation time course (Fig. 5). Immunoblot with $\mathrm{AT}_{1} \mathrm{R}$ antibody showed a single band of $\sim 49 \mathrm{kDa}$, consistent with the reported size of the $\mathrm{AT}_{1} \mathrm{R}$ (Fig. 6).

A series of co-immunoprecipitation experiments using polyclonal anti- $\mathrm{AT}_{1} \mathrm{R}$ antibody were carried out in Ang II-stimulated neuronal cells to further confirm an interaction between the $\mathrm{AT}_{1} \mathrm{R}$ and MAP kinase. Figure $7 A$ shows that MAP kinase immunoreactivity co-precipitated with $\mathrm{AT}_{1} \mathrm{R}$ in Ang II-treated neurons. Maximal association was observed in 5-10 min. In-gel kinase assay was carried out in immunoprecipitated $\mathrm{AT}_{1} \mathrm{R}$ preparation isolated from Ang II-treated neurons. Figure $7 B$ shows a significant MAP kinase activity in these immunoprecipitates: an approximately threefold increase was observed in $10 \mathrm{~min}$, and only one band was observed. This is consistent with our previous observation that Ang II stimulates only one isoform of MAP kinase in neurons (Yang et al., 1996a). Ang II receptor subtype specificity 
Figure 7. Co-immunoprecipitation of $\mathrm{AT}_{1} \mathrm{R}$ with MAP kinase in Ang II-treated neurons. $A, \quad \mathrm{Co}$ immunoprecipitation of MAP kinase by $\mathrm{AT}_{1} \mathrm{R}$ antibody. Neuronal cultures were incubated with $100 \mathrm{~nm}$ Ang II for indicated time periods. Cell lysates were prepared and subjected to immunoprecipitation with the polyclonal $\mathrm{AT}_{1} \mathrm{R}$ antibody as described in Materials and Methods. Immunoprecipitates were electrophoresed on SDS-PAGE and immunoblotted with MAP kinase antibody as described in Materials and Methods. Membranes were also immunoblotted with $\mathrm{AT}_{1} \mathrm{R}$ antibody to normalize for equal loadblot depicting a band corresponding to MAP kinase (P42); bottom, quantitation of radioactive bands corresponding to MAP kinase. Data are mean $\pm \operatorname{SE}(n=3)$. Asterisks shows significantly different $(p<0.05)$ from zero time. $B$, MAP kinase activity in co-immunoprecipitates. Immunoprecipitates, prepared essentially as described in $A$, were used to run in-gel kinase assay to measure MAP kinase activity as described elsewhere (Yang et. al., 1996a). ing. Top, A representative immuno-
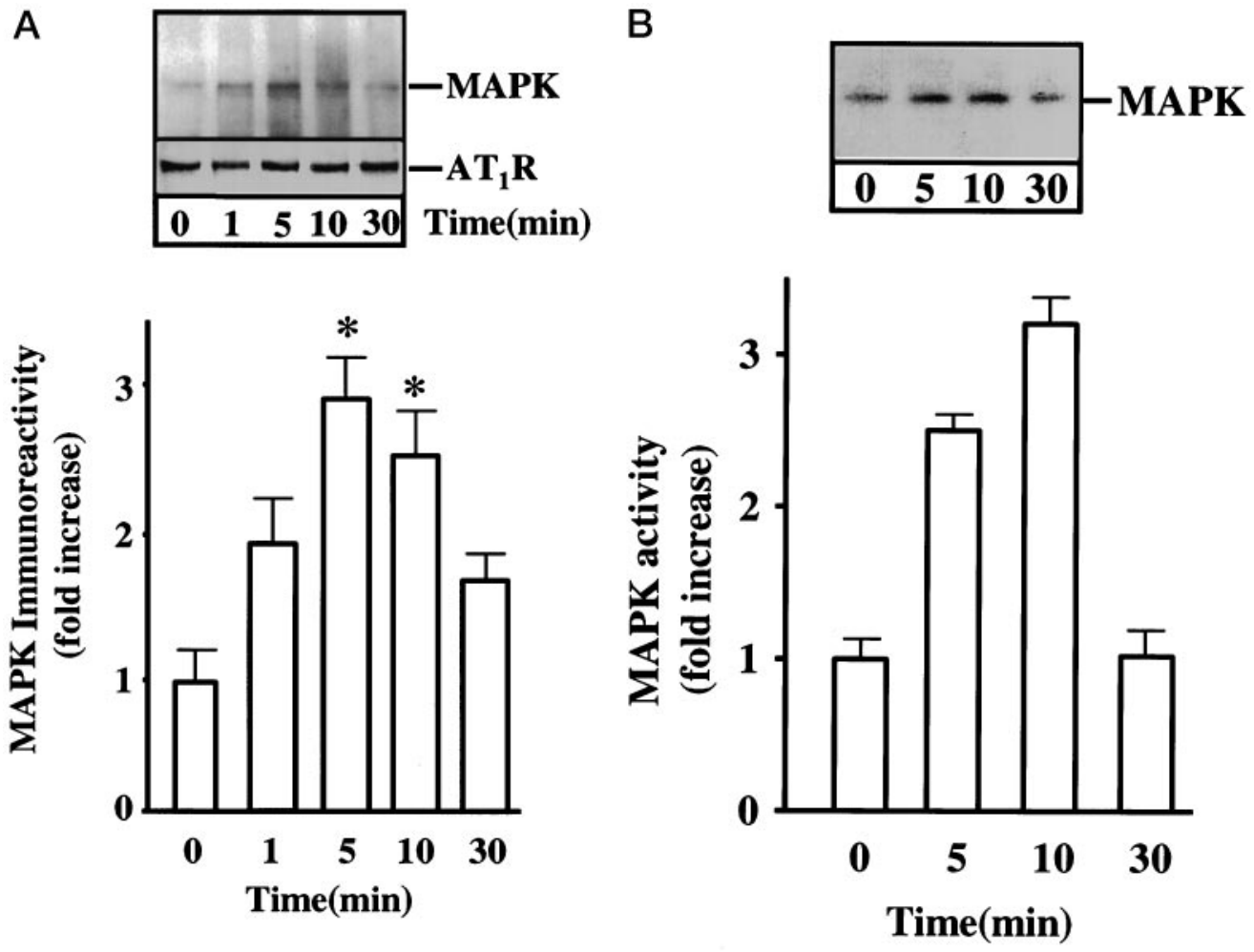

was determined in Ang II-induced interaction of $\mathrm{AT}_{1} \mathrm{R}$ with MAP kinase. Co-precipitation of MAP kinase with $\mathrm{AT}_{1} \mathrm{R}$ was blocked by losartan, an $\mathrm{AT}_{1} \mathrm{R}$ antagonist, and not by PD123319, an $\mathrm{AT}_{2} \mathrm{R}$ antagonist (Fig. 8). Further evidence for co-immunoprecipitation of these two proteins was obtained by the observation that immunoprecipitation of Ang II-treated neurons with MAP kinase antibody contained a protein band of $\sim 49 \mathrm{MW}$ corresponding to $\mathrm{AT}_{1} \mathrm{R}$ (data not shown).

Next, neuronal cultures were pretreated with $10 \mu \mathrm{M}$ PD98059 for $30 \mathrm{~min}$, a relatively selective inhibitor of MAP kinase-kinase under these conditions (Alessi et al., 1995), to determine its effect on Ang II-induced phosphorylation of $\mathrm{AT}_{1} \mathrm{R}$. Figure 9 shows that PD98059 completely attenuated Ang II-induced $\mathrm{AT}_{1} \mathrm{R}$ phosphorylation. PD98059 by itself had no effect. Figure $10 A$ shows that preincubation of neurons with $10 \mu \mathrm{M}$ PD98059 also blocked Ang II-induced translocation of $\mathrm{AT}_{1} \mathrm{R}$ immunoreactivity into the nucleus. In addition, confocal microscopy of nuclei isolated from PD98059-treated neurons showed no $\mathrm{AT}_{1} \mathrm{R}$ immunoreactivity after Ang II treatment (Fig. 10B). Collectively, these observations suggest that Ang II stimulation of MAP kinase may be involved in $\mathrm{AT}_{1} \mathrm{R}$ phosphorylation and its translocation to the nucleus.

Finally, the effect of phosphorylation by MAP kinase on binding of $\left[{ }^{125} \mathrm{I}\right]-\mathrm{Sar}^{1}$-Ile $^{8}$-Ang II to $\mathrm{AT}_{1}$ Rs was measured to determine whether phosphorylated receptors retain $\mathrm{AT}_{1}$ binding activity. Figure $11 A$ shows that MAP kinase-phosphorylated $\mathrm{AT}_{1} \mathrm{R}$ had very little $\left[{ }^{125} \mathrm{I}\right]-$ Sar $^{1}$-Ile ${ }^{8}$-Ang II binding activity compared with nonphosphorylated receptor. This lack of binding was the result of a significant decrease in the $B_{\max }$ for phosphorylated receptors (79 $\pm 8 \mathrm{fmol} / \mathrm{mg}$ protein) compared with control $(17 \pm 5 \mathrm{fmol} / \mathrm{mg}$ protein) (Fig. 11B).

\section{DISCUSSION}

Observations presented in this study demonstrate that Ang II stimulates phosphorylation of $\mathrm{AT}_{1} \mathrm{R}$, which is associated with its
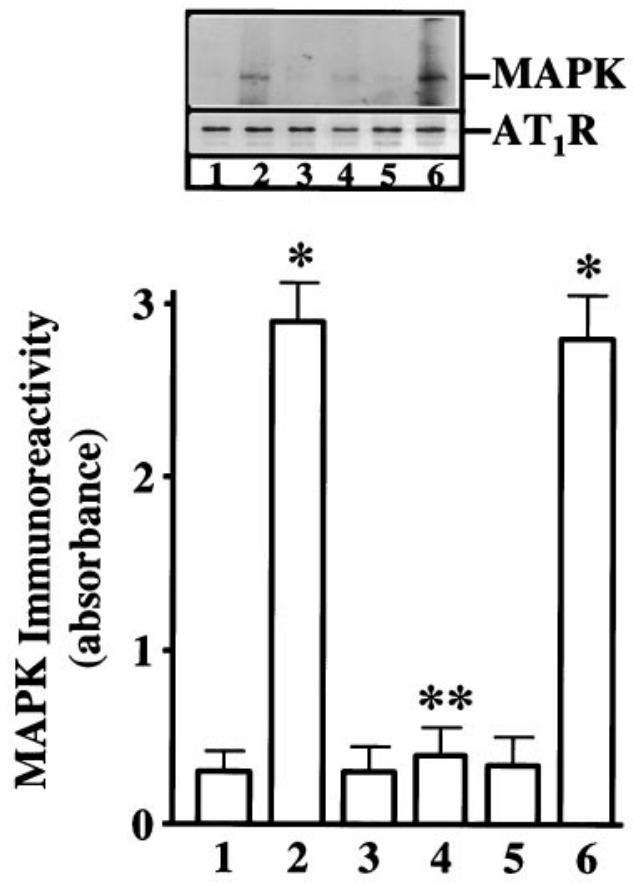

Figure 8. Effect of Ang II receptor antagonists on coimmunoprecipitation of $\mathrm{AT}_{1} \mathrm{R}$ with MAP kinase. Neuronal cultures were incubated without $(1,3,5)$ or with $(2,4,6) 100 \mathrm{~nm}$ Ang II for $10 \mathrm{~min}$ in the presence of $10 \mu \mathrm{M}$ losartan $(3,4)$ or $10 \mu \mathrm{M} \operatorname{PD} 123319(5,6)$. Cell lysates were immunoprecipitated with $\mathrm{AT}_{1} \mathrm{R}$ antibody, and the immunoprecipitate was subjected to SDS-PAGE and immunoblotted with MAP kinase antibody as described in Materials and Methods. Top, A representative immunoblot; bottom, quantitation of bands corresponding to MAP kinase. Data are mean $\pm \mathrm{SE}(n=3)$. Single asterisks indicate significantly different $(p<0.05)$ from control (2 and vs 1$)$. Double asterisk indicates significantly different from Ang II-treated cells (4 vs 2). 

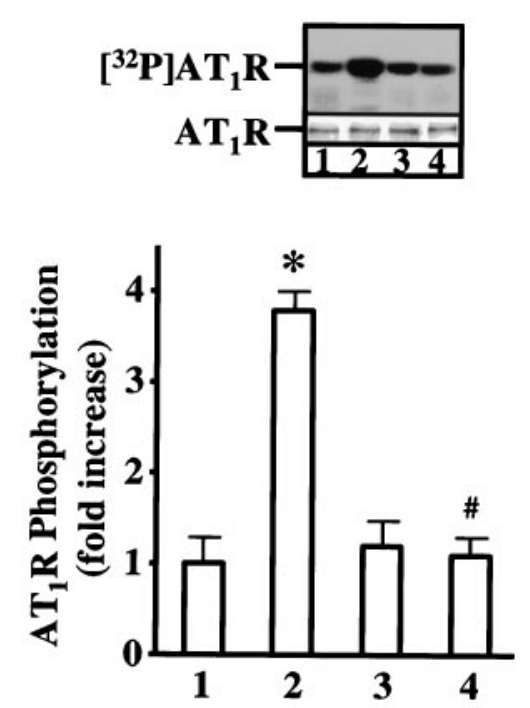

Figure 9. Effect of PD98059 on Ang II-induced phosphorylation of $\mathrm{AT}_{1}$ Rs. Neuronal cultures were prelabeled with $\left[{ }^{32} \mathrm{P}\right]$-orthophosphate for $4 \mathrm{hr}$ and incubated without $(1,3)$ or with $(2,4) 100 \mathrm{~nm}$ Ang II for $10 \mathrm{~min}$ in the absence $(1,2)$ or presence $(3,4)$ of $10 \mu \mathrm{M}$ PD98059. Top, Representative autoradiogram; bottom, data (mean $\pm \mathrm{SE} ; n=3$ ) were normalized for equal loading by immunoblotting of the membranes with $\mathrm{AT}_{1} \mathrm{R}$ antibody, essentially as described for Figure 1. Asterisk indicates significantly different from $1(p<0.05)$; \# indicates significantly different from $2(p<0.05)$.

translocation into the nucleus. Evidence is also presented to establish that MAP kinase is involved in this phosphorylation and nuclear targeting of $\mathrm{AT}_{1} \mathrm{R}$.

Ang II stimulates phosphorylation of neuronal $\mathrm{AT}_{1} \mathrm{R}$. The site(s) of this phosphorylation could be localized in the intracellular domain, consistent with the presence of threonine, serine, and tyrosine residues in this region of the receptor (Catt et al., 1993; Inagami et al., 1993). Phosphorylation of neuronal $\mathrm{AT}_{1} \mathrm{R}$ was associated with its translocation into the nucleus. The presence of nuclear $\mathrm{AT}_{1} \mathrm{R}$ in neurons is consistent with earlier reports in which nuclear Ang II receptors have been demonstrated in hepatocytes (Booz et al., 1992; Tang et al., 1992). The precise mechanism involved in $\mathrm{AT}_{1} \mathrm{R}$ phosphorylation remains to be worked out fully; however, our data strongly support the notion that MAP kinase plays a crucial role. Ang II stimulates MAP kinase in a Ras-Raf-1-dependent process (Yang et al., 1996a). Stimulation of MAP kinase leads to the propagation of downward signals, which ultimately results in the regulation of neuromodulatory actions of Ang II (Lu et al., 1996b; Yang et al., 1996a). The data presented here suggest another important role of MAP kinase activation by Ang II. They show that MAP kinase is involved in the phosphorylation of $\mathrm{AT}_{1} \mathrm{Rs}$. Evidence for this includes the following: (1) exogenous MAP kinase phosphorylates $\mathrm{AT}_{1} \mathrm{R}$; (2) MAP kinase co-immunoprecipitates with $\mathrm{AT}_{1} \mathrm{R}$; (3) endogenous MAP kinase, co-immunoprecipitated with the receptor, also phosphorylates $\mathrm{AT}_{1} \mathrm{R}$; (4) the $\mathrm{AT}_{1} \mathrm{R}$ antagonist losartan blocks both co-immunoprecipitation and colocalization of $\mathrm{AT}_{1} \mathrm{R}$ with MAP kinase; (5) MAP kinase-kinase inhibition by PD98059 attenuates Ang II-induced $\mathrm{AT}_{1} \mathrm{R}$ phosphorylation; and (6) PD98059 also blocks Ang II-induced nuclear translocation of $\mathrm{AT}_{1}$ Rs. Collectively, these observations provide strong evidence for a direct role of MAP kinase in $\mathrm{AT}_{1} \mathrm{R}$ phosphorylation. Additional support for this view is evident in the presence of a MAP kinase recognition sequence (amino acids ${ }^{232-233}$ ) in the $\mathrm{AT}_{1 \mathrm{~b}} \mathrm{R}$ subtype, which together with the $\mathrm{AT}_{1 \mathrm{a}}$ subtype are shown to be present in our neuronal cells (Raizada et al., 1993). It is pertinent, however, to add a note of caution in our conclusion. Alternative possibilities of the involvement of other GRKs, such as $\beta A R K 1$, also should not be ruled out at the present time in Ang II-induced $\mathrm{AT}_{1} \mathrm{R}$ phosphorylation. For example, it may be possible that Ang II stimulates MAP kinase, which activates other GRKs that in turn phosphorylate the $\mathrm{AT}_{1} \mathrm{R}$. Such a hypothesis is supported by recent data demonstrating $\mathrm{AT}_{1} \mathrm{R}$ phosphorylation by $\beta \mathrm{ARK} 1$ (Oppermann et al., 1996). This is supported further by the lack of MAP kinase recognition sequence in the $\mathrm{AT}_{1 \mathrm{a}} \mathrm{R}$ subtype. Thus, whether MAP kinase indirectly ( $\mathrm{AT}_{1 \mathrm{a}}$ and $\mathrm{AT}_{1 \mathrm{~b}}$ subtypes) or directly $\left(\mathrm{AT}_{1 \mathrm{~b}}\right)$ phosphorylates the receptor remains to be elucidated.

Three questions arise from these observations concerning the role of MAP kinase. First, is MAP kinase involved in the translocation of $\mathrm{AT}_{1} \mathrm{R}$ to the nucleus? It is tempting to suggest that MAP kinase, in addition to phosphorylating $\mathrm{AT}_{1} \mathrm{R}$, also may phosphorylate relevant protein(s) in the nuclear pore complex so that the phosphorylated $\mathrm{AT}_{1} \mathrm{R}$ and other signaling molecules, including MAP kinase itself, are transported across the nuclear membrane. The following evidence supports this notion. (1) MAP kinase is localized predominately around the nuclear membrane in the neurons and is translocated into the nucleus after stimulation with Ang II (Lu et al., 1996b), and (2) MAP kinase plays a role in the translocation of other neuronal signaling proteins such as Stat3 in neurons. Our studies have indicated that Ang IImediated translocation of Stat 3 requires activation of MAP kinase, because its depletion causes accumulation of Stat 3 in the cytoplasmic compartment (unpublished observation). (3) p62 and gp210, two proteins of nuclear pore complex that are involved in nuclear translocation of cytoplasmic proteins, contain MAP kinase phosphorylation motifs (Wozniak et al., 1989). This would suggest that MAP kinase phosphorylation of these proteins may be significant in the nuclear translocation of $\mathrm{AT}_{1} \mathrm{R}$.

Second, is phosphorylation of $\mathrm{AT}_{1} \mathrm{R}$ necessary for its nuclear targeting? Our observations showing that the MAP kinase kinase inhibitor PD98059 inhibits both Ang II-induced $\mathrm{AT}_{1} \mathrm{R}$ phosphorylation and its nuclear translocation strongly support the role of phosphorylation. Third, how does $\mathrm{AT}_{1} \mathrm{R}$, a plasma membrane protein, transport across the nuclear membrane? It has been suggested that the presence of a nuclear localization signal (NLS) in many peptide hormones and their membrane receptors plays an important role in the translocation into the nucleus (Scearce et al., 1993; Jans, 1994; Radulescu, 1995). For example, it has been suggested (Radulescu, 1995) that the presence of NLS in the $\alpha$ subunit of insulin receptor is the key in the nuclear translocation of this receptor and in the effects of insulin on gene regulation. Thus, we hypothesized that the $\mathrm{AT}_{1} \mathrm{R}$ may contain NLS consensus sequence, which could guide this protein across the nuclear membrane. It was intriguing to find two consensus sequences in this receptor that hold the potential for NLS (Dingwall et al., 1988; Kang et al., 1994). They are amino acids $304-310$ on the C-terminal tail (LGKKFKK) and 221-225 on the third intracellular loop (ALKKA). This would confirm that, like the insulin receptor, $\mathrm{AT}_{1} \mathrm{R}$ is translocated into the nucleus and that the mechanism of this translocation involves these NLSs. Mutagenesis studies involving this NLS region of the $\mathrm{AT}_{1} \mathrm{R}$ will be needed to confirm this point of view.

Finally, the role of $\mathrm{AT}_{1} \mathrm{R}$ phosphorylation and its translocation into the nucleus on persistent stimulatory actions of Ang II on neuromodulation needs to be examined. Our data show that Ang 
A
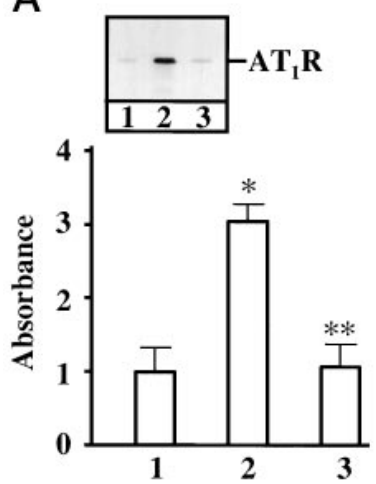

B

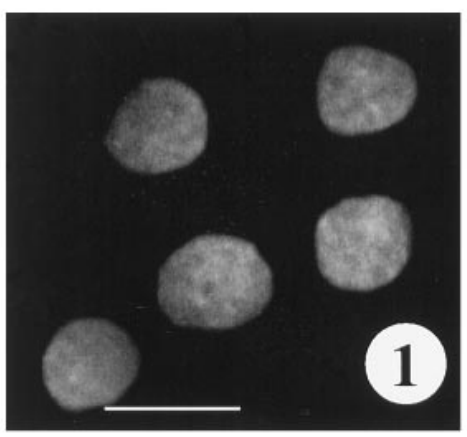

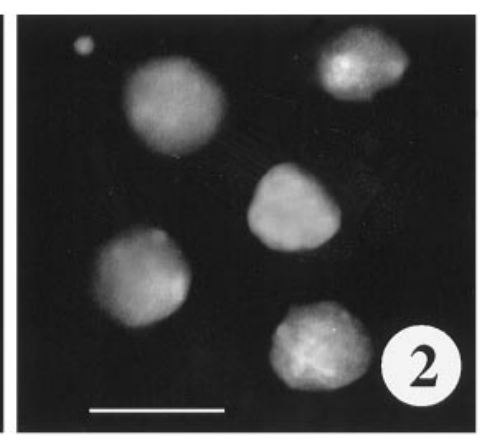

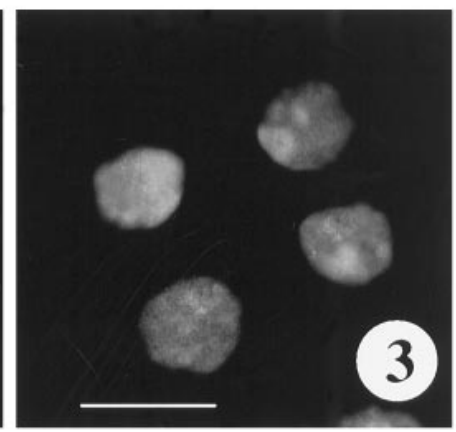

Figure 10. Effect of PD98059 on Ang II-induced $\mathrm{AT}_{1} \mathrm{R}$ translocation into the nuclear fraction. $A$, Immunoblotting of $\mathrm{AT}_{1} \mathrm{R}$ in nuclear fraction. Neuronal cultures were incubated without (1) or with $(2,3) 100 \mathrm{nM}$ Ang II for $30 \mathrm{~min}$ at $37^{\circ} \mathrm{C}$ in the absence $(1,2)$ or presence (3) of $10 \mu \mathrm{M}$ PD98059. Neurons were collected, and the nuclear fraction was isolated and subjected to immunoprecipitation with the $\mathrm{AT}_{1} \mathrm{R}$ polyclonal antibody. Immunoprecipitates were analyzed on SDS-PAGE as described in Materials and Methods. Top, Representative immunoblot; bottom, data are presented as absorbance of AT $\mathrm{R}$ band density and are mean \pm SE of three experiments. Single asterisk indicates significantly different from $1(p<0.05)$; double asterisk indicates significantly different from $2(p<0.05)$. $B$, Confocal microscopic images of $\mathrm{AT}_{1} \mathrm{R}$ immunoreactivity in nuclei. Neurons were treated without $(1)$ or with $(2,3) 100 \mathrm{nM}$ Ang II in the absence (2) or presence (3) of $10 \mu \mathrm{M}$ PD98059 for $30 \mathrm{~min}$ at $37^{\circ} \mathrm{C}$. Nuclei were isolated, fixed on slides, and subjected to confocal microscopic analysis with the use of monoclonal $\mathrm{AT}_{1} \mathrm{R}$ antibody, essentially as described in Materials and Methods.

Figure 11. Effect of MAP kinase-mediated phosphorylation on binding of $\left[{ }^{125} \mathrm{I}\right]-\mathrm{Sar}^{1}-\mathrm{Ile}^{8}-$ Ang II to $\mathrm{AT}_{1} \mathrm{R}$. Neuronal cell lysates were used to immunoprecipitate $\mathrm{AT}_{1} \mathrm{R}$. Immunoprecipitates containing $\sim 30$ fmol ${ }^{125} \mathrm{I}_{-} \mathrm{Sar}^{1}$ Ile ${ }^{8}$-Ang II binding activity were used to incubate without $(\square)$ or with $(\mathbf{})$ 0.3 U of MAP kinase, essentially as described in legends to Figures 5 and 6 and in Materials and Methods. This was followed by determination of the ability of phosphorylated $\mathrm{AT}_{1} \mathrm{R}$ to bind $\left[{ }^{125} \mathrm{I}\right]-$ $\mathrm{Sar}^{1}$-Ile ${ }^{8}$-Ang II. $A$, Competition-inhibition of $\left[{ }^{125} \mathrm{I}\right]-\mathrm{Sar}^{1}$-Ile $\mathrm{e}^{8}$-Ang II binding in control (ם) and MAP kinase-phosphorylated $(\bullet)$ receptors with indicated concentrations of losartan as described in Materials and Methods. Each point represented triplicate samples and mean $\pm \mathrm{SE}$ of three experiments. $B$, Scatchard analysis of data from Figure $11 A$.

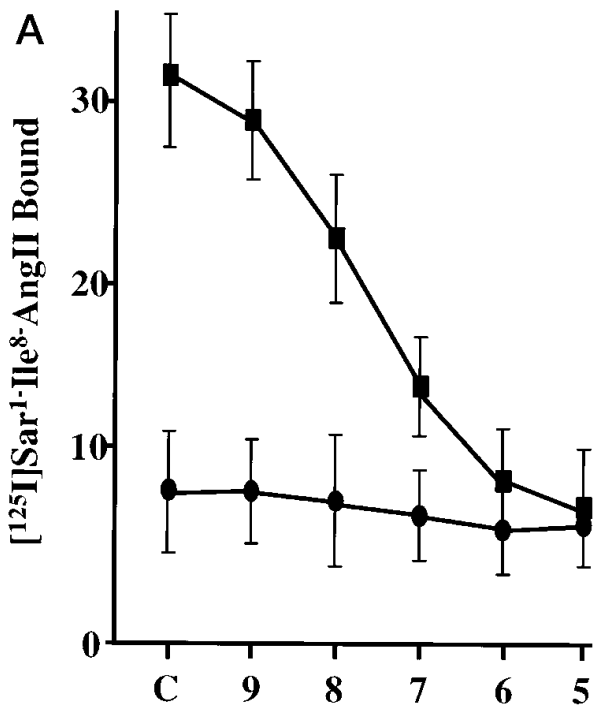

$\operatorname{Losartan}(-\log M)$
B

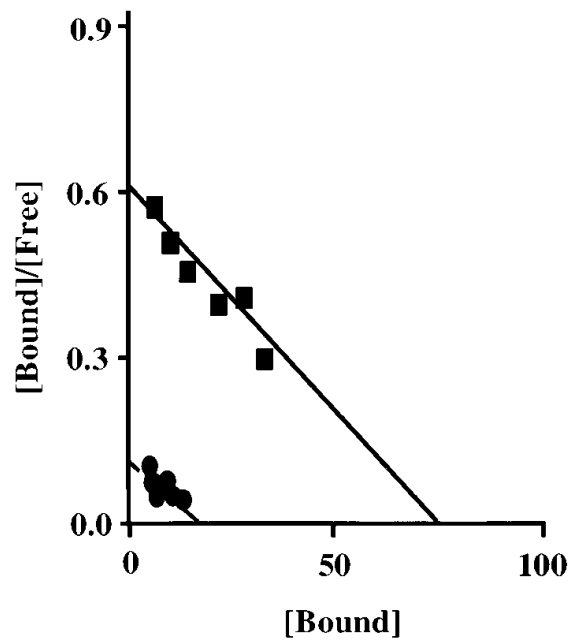

II stimulates phosphorylation of $\mathrm{AT}_{1} \mathrm{Rs}$, which is associated with their internalization. Also, phosphorylated $\mathrm{AT}_{1} \mathrm{R}$ lacks Ang II binding activity. This would suggest that, like other GPCRs, Ang II induces events associated with $\mathrm{AT}_{1} \mathrm{R}$ desensitization (Boulay et al., 1994; Kai et al., 1994). Norepinephrine transporter and TH activities, however, are chronically stimulated by Ang II for 4-24 hr despite this desensitization (Lu et al., 1996a; Yu et al., 1996). On the basis of our data, it is tempting to suggest that a selective targeting of certain populations of $\mathrm{AT}_{1} \mathrm{Rs}$ to the nucleus where it may act as a transcription regulator may hold the key to explaining the chronic neuromodulatory response of Ang II. Additional experiments will be needed to clarify the relationship between Ang II-mediated internalization-induced desensitization and nuclear translocation of $\mathrm{AT}_{1} \mathrm{Rs}$ with chronic actions of Ang II in the neurons. Nonetheless, these observations are relevant, because they demonstrate three unique features of this GPCR. (1) Phosphorylation of the receptor is MAP kinase-mediated; (2) chronic stimulation of cellular response is not related to desensitization of the receptor; and (3) the presence of NLS in the $\mathrm{AT}_{1} \mathrm{R}$ sequence may be the basis of its translocation into the nucleus.

\section{REFERENCES}

Abmayr SB, Workman J (1992) Preparation of nuclear and cytoplasmic extracts from mammalian cells. In: Short protocols in molecular biology (Ausubel FM, Brent R, Kingston R, Moore DD, Seidman JG, Smith JA, Struhl K, eds), pp 3-5. New York: Wiley.

Abramowski D, Staufenbiel M (1995) Identification of the 5-hydroxytryptamine-2c receptor as a $60-\mathrm{kDa} \mathrm{N}$-glycosylated protein in choroid plexus and hippocampus. J Neurochem 65:782-790.

Alessi DR, Cuenda A, Cohen P, Dudley DT, Saltiel AR (1995) PD98059 is a specific inhibitor of the activation of mitogen-activated protein kinase in vitro and in vivo. J Biol Chem 270:27489-27494.

Barker S, Marchant W, Ho MM, Puddefoot JR, Hinson JP, Clark AJL, Vinson GP (1993) A monoclonal antibody to a conserved sequence in the extracellular domain recognizes the angiotensin $\mathrm{II}_{\mathrm{AT}_{1}}$ receptor in mammalian tissues. J Mol Endocrinol 11:241-245. 
Booz GW, Gonrad KM, Hess AL, Singer HA, Baker KM (1992) Angiotensin II binding sites on hepatocyte nuclei. Endocrinology 130:3641-3649.

Boulay G, Chretien L, Richard D, Guillemette G (1994) Short-term desensitization of the angiotensin II receptor of bovine adrenal glomerulosa cells corresponds to a shift from a high to a low affinity state. Endocrinology 135:2130-2136.

Burgering BM, Bos JL (1995) Regulation of Ras-mediated signalling: more than one way to skin a cat. Trends Biochem Sci 20:18-22.

Catt KJ, Sandberg K, Balla T (1993) Angiotensin II receptor and signal transduction mechanisms. In: Cellular and molecular biology of reninangiotensin system (Raizada MK, Phillips MI, Sumners C, eds), pp 307-356. Boca Raton, FL: CRC.

Clegg JS (1984) Properties and metabolism of the aqueous cytoplasm and its boundaries. Am J Physiol 246:R133-R151.

Dingwall C, Robbins J, Dilworth SM, Roberts BL, Richardson WD (1988) The nucleoplasmin nuclear location sequence is larger and more complex than that of SV40 large T antigen. J Cell Biol 107:841-849.

Freedman NJ, Liggett SB, Drachman DE, Pei G, Caron MG, Lefkowitz RJ (1995) Phosphorylation and desensitization of human $\beta_{1}$ adrenergic receptor: involvement of G-protein-coupled receptor kinase and cAMP-dependent protein kinase. J Biol Chem 270:17953-17961.

Gerace L (1986) Nuclear lamina and organization of nuclear architecture. Trends Biochem Sci 11:443-446.

Hiraoka Y, Swedlow IR, Paddy MR, Agard DA, Sedat JW (1991) Threedimensional multiple wavelength phenomena. Semin Cell Biol 2:153-165.

Inagami T, Iwai N, Sasaki K, Yamano Y, Bardhan S, Chaki S, Guo DF, Furuta H (1993) Cloning, expression, and regulation of angiotensin II receptors. In: Cellular and molecular biology of renin-angiotensin system (Raizada MK, Phillips MI, Sumners C eds), pp 273-291. Boca Raton, FL: CRC.

Inglese J, Koch WJ, Touhara K, Lefkowitz RJ (1995) $G_{\beta \gamma}$ interactions with $\mathrm{PH}$ domains and Ras-MAP-K signalling pathways. Trends Biochem Sci 20:151-156.

Jans DA (1994) Nuclear signalling pathways for polypeptide ligands and their membrane receptors? FASEB J 8:841-847.

Kai H, Griendling KK, Lassegue B, Ollerenshaw JD, Runge MS, Alexander RW (1994) Agonist-induced phosphorylation of the vascular type-1 angiotensin II receptor. Hypertension 24:523-527.

Kang KI, Devin J, Cadepond F, Jibard N, Guiochon-Mantel A, Baulien E, Catelli M (1994) In vivo functional protein-protein interaction: nuclear targeted hsp 90 shifts cytoplasmic steroid receptor mutants into the nucleus. Proc Natl Acad Sci USA 91:340-344.

Kato S, Endoh H, Masuhiro Y, Kitamoto T, Uchiyama S, Sasaki H, Masushige S, Gotoh Y, Nishida E, Kawashima H, Metzger D, Chambon P (1995) Activation of the estrogen receptor through phosphorylation by mitogen-activated protein kinase. Science 270:1491-1494.

Lefkowitz RJ (1993) G-protein-coupled receptor kinase. Cell 74: 409-412.

Lohse MJ (1993) Molecular mechanisms of membrane receptor desensitization. Biochim Biophys Acta 1179:171-188.

Lu D, Yu K, Paddy MR, Rowland NE, Raizada MK (1996a) Regulation of norepinephrine transport system by angiotensin II in neuronal cultures of normotensive and spontaneously hypertensive rat brains. Endocrinology 137:763-772.

Lu D, Yang H, Raizada MK (1996b) Angiotensin II regulation of neuromodulation: downstream signalling mechanism from activation of mitogen-activated protein kinase. J Cell Biol, 135:1609-1617.

Lubke J, Wood MJ, Clarke DJ (1994) Morphological assessment of grafted rat and mouse cortical neurons: a light and electron microscopic study. J Comp Neurol 341:78-94.
Morrison P, Takishima K, Rosner MR (1993) Role of threonine residues in regulation of the epidermal growth factor receptor by protein kinase $\mathrm{C}$ and mitogen-activated protein kinase. J Biol Chem 268:15536-15543.

Oppermann M, Freedman NJ, Alexander RW, Lefkowitz RJ (1996) Phosphorylation of the Type 1A angiotensin II receptor by G-proteincoupled receptor kinases and protein kinase C. J Biol Chem 271:13266-13272.

Paxton WG, Runge M, Horaist C, Cohen C, Alexander RW, Bernstein KE (1993) Immunohistochemical localization of rat angiotensin II $\mathrm{AT}_{1}$ receptor. Am J Physiol 264:F989-F995.

Paxton WG, Marrero MB, Klein JD, Delafontaine P, Berk BC, Bernstein $\mathrm{KE}$ (1994) The angiotensin II $\mathrm{AT}_{1}$ receptor is tyrosine and serine phosphorylated and can serve as a substrate for the src family of tyrosine kinases. Biochem. Biophys. Res. Commun. 200:260-267.

Permont RT, Inglese J, Lefkowitz RJ (1995) Protein kinase that phosphorylate activated G protein-coupled receptors. FASEB J 9:175-182.

Radulescu RT (1995) Insulin receptor $\alpha$-subunit: a putative gene regulatory molecule. Med Hypotheses 45:107-111.

Raizada MK, Muther TF, Sumners C (1984) Increased angiotensin II specific receptors in neuronal culture of spontaneously hypertensive rat brain. Am J Physiol 247:C364-C372.

Raizada MK, Lu D, Tang W, Kurian P, Sumners C (1993) Increased angiotensin II type-1 receptor gene expression in neuronal cultures from spontaneously hypertensive rats. Endocrinology 132:1715-1722.

Raizada MK, Lu D, Sumners C (1994) $\mathrm{AT}_{1}$ receptors and angiotensin actions in the brain and neuronal cultures of normotensive and hypertensive rats. In: Current concepts: tissue renin-angiotensin system as local regulators in reproductive and endocrine organs (Mulhopadhyay A, Raizada MK, eds), pp 331-348. New York: Plenum.

Scearce LM, Laz TM, Hazel TG, Lau LF, Taub R (1993) RNR-1, a nuclear receptor in the NGFI-B/Nar77 family that is rapidly induced in regenerating liver. J Biol Chem 268:8855-8861.

Shaw G (1995) The pleckstrin homology domain: an intriguing multifunctional protein module. BioEssays 18:35-46.

Steckelings V, Lebrun C, Quadri F, Veltman A, Unger T (1992) Role of brain angiotensin in cardiovascular regulation. J Cardiovasc Pharmacol 19[Suppl 6]:S73-S79.

Swedlow JR, Sedat JW, Agard DA (1993) Multiple chromosomal populations of topoisomerase II detected in vivo by time-lapse, threedimensional wide-field microscopy. Cell 73:97-108.

Tang SS, Rogg H, Schumacher R, Dzau VJ (1992) Characterization of nuclear angiotensin II binding sites in rat liver and comparison with plasma membrane receptor. Endocrinology 131:374-380.

Van Corven EJ, Hordijk PL, Medema RH, Bos JL, Moolenaas WH (1993) Pertussis toxin-sensitive activation of $\mathrm{p} 21^{\text {ras }}$ by G-proteincoupled receptor agonist in fibroblasts. Proc Natl Acad Sci USA 90:1257-1261.

Wozniak RW, Bartnik E, Blobel G (1989) Primary structure analysis of an integral membrane glycoprotein of the nuclear pore. J Cell Biol 108:2083-2092.

Yang H, Lu D, Yu K, Raizada MK (1996a) Regulation of neuromodulatory actions of angiotensin II in the brain neurons by the Rasdependent mitogen-activated protein kinase pathway. J Neurosci 16:4047-4058.

Yang H, Lu D, Raizada MK (1996b) Lack of cross-talk between $\alpha 1$ adrenergic and $\mathrm{AT}_{1}$ receptors in neurons of spontaneously hypertensive rat brain. Hypertension 27:1277-1283.

Yu K, Lu D, Rowland NE, Raizada MK (1996) Angiotensin II regulation of tyrosine hydroxylase gene expression in the neuronal cultures of normotensive and spontaneously hypertensive rats. Endocrinology 137: 2503-2513. 